\title{
رخصة البناء كآلية للحد من التلوث البصري
}

\section{Planning permission as a mechanism to reduce visual pollution}

\author{
تاريخ الاستلام :2019/05/15؛ تاريخ القبول : 2019/05/30
}

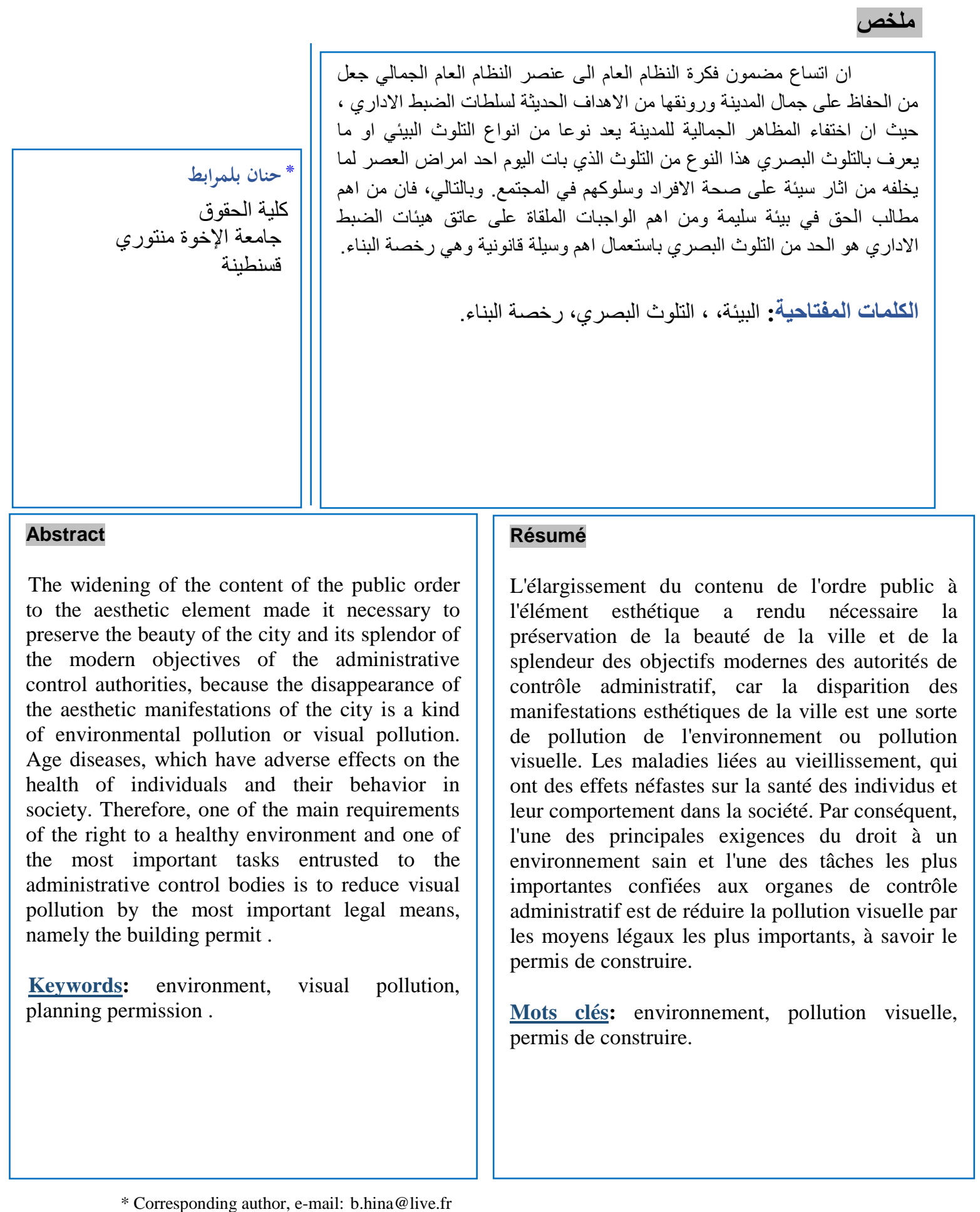

(C) جامعة الاخوة منتوري قسنطينة 1، الجزائر 2019. 
مقدمة:

لقد شهدت المدينة الجزائرية العديد من التحولات العمر انية و التي فرضتها الزيادة

المتسار عة للسكان ومتطلباتهم المختلفة من العمران (سكنية ،تجارية، خدماتية....) ، ونتيجة لتسارع وتيرة هذا الطلب فقدت العديد منها التحكم في مجالها العدر اني وأنتجت الته

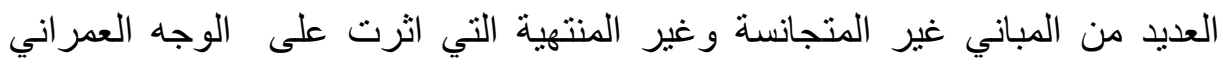

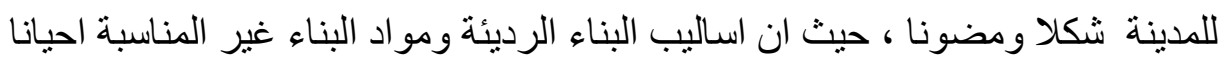

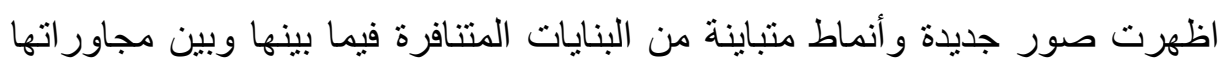

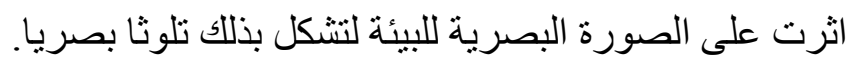
بالتالي اصبحت الحاجة الى مدينة جميلة وبيئة نظيفة من التلوث البيائي بصفئة بلئة عامة والتلوث البصري بصفة خاصة مرهون بمدى التحكم في التعمير وتنظيمه التها

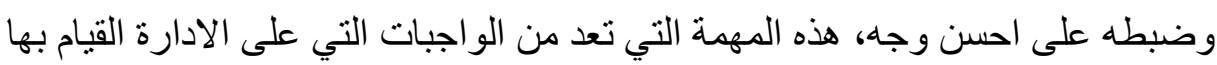

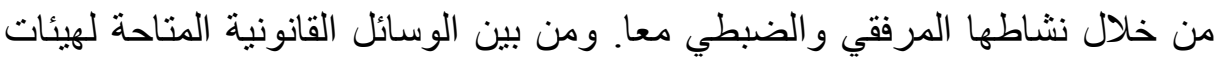

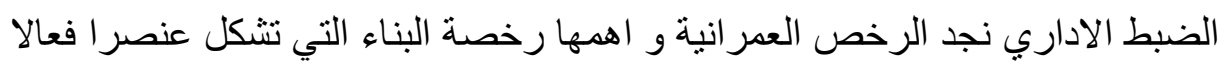

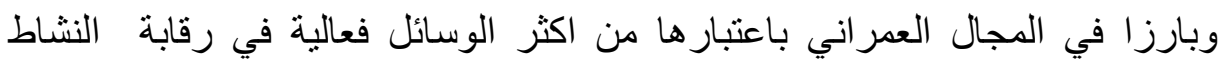

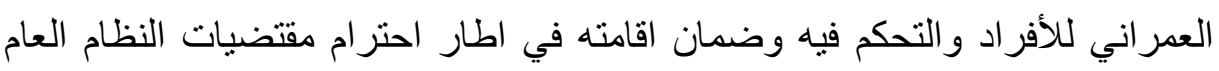

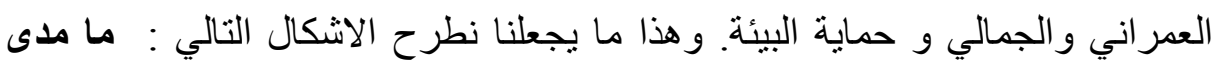

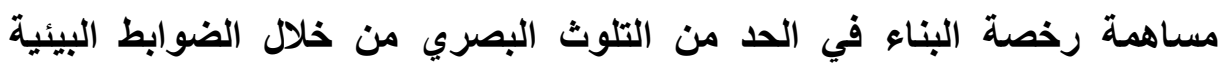

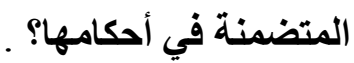

وللإجابة على هذا الاشكال تم اعتماد الخطة التالية:

المحور الأول: التلوث البصري كنتيجة لاختفاء المظاهر الجمالية للمدينة. المحور الثاني: دور رخصة البناء في الحفاظ على المظاهر الجمالية للمدينة. المحور الأول: التلوث البصري كنتيجة لاختفاء المظاهر الجمالية للمدينة:

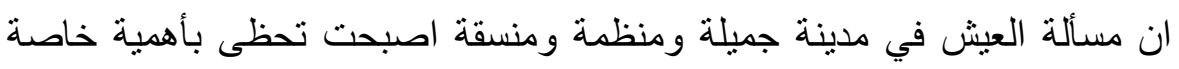

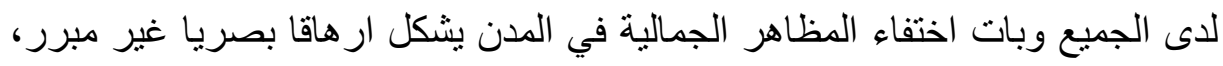

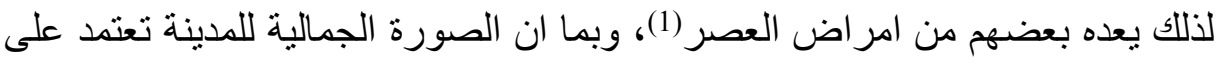

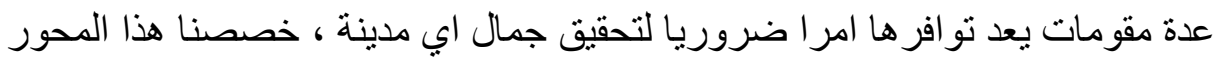

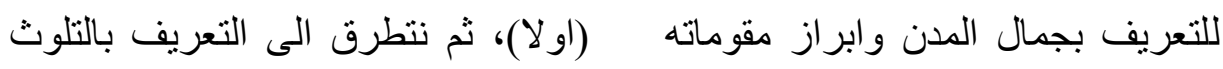
البصري و تبيان مظاهره ( ثانيا). اولا: التعريف بجمال المدن ومقوماته: عند الكلام عن وظيفة الضبط الاداري في تحقيق جمال المدن لا بد من التعريف به به التهان و حصر اهم مقوماته. 1 1

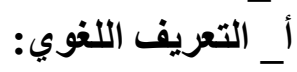

الجمال مصدر الجميل، و هو الحسن ، ويكون في الفعل والخلق(2). وقد جاء في

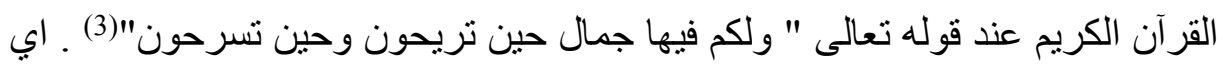

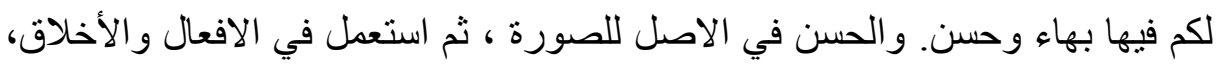




$$
\text { فالجمال يقع ايضا على الصور و المعاني. }
$$

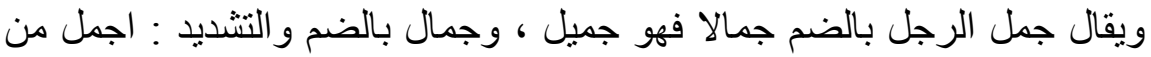

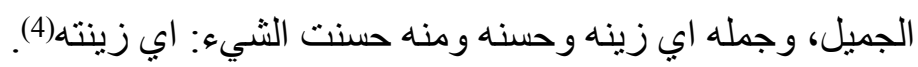

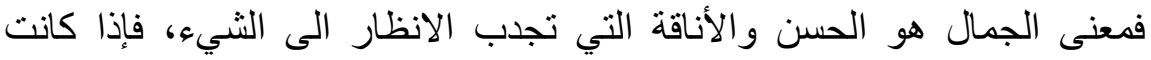
المدينة تحمل هذه الصفات فلابد ان توصف بالجمال لنظارنها وحسنها وكمال اوصافها

وتناسقها. (5)

وبما ان فقهاء القانون العام قد درجوا على ذكر مصطلح الجمال مع مصطلحين

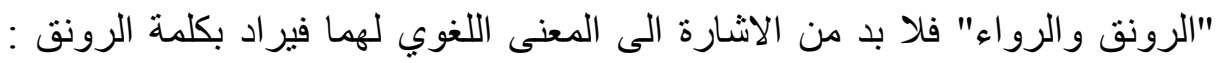

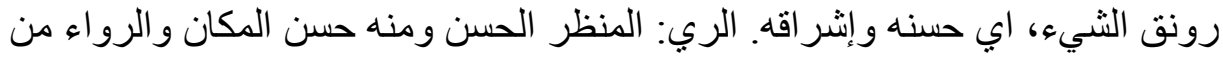
الماء : اي العذب و الرواء : حسن المنظر وائه وماء الوجه(6).

و على هذا الاساس فإن تسمية هذا العنصر من عناصر النظام العام بـ " جمال

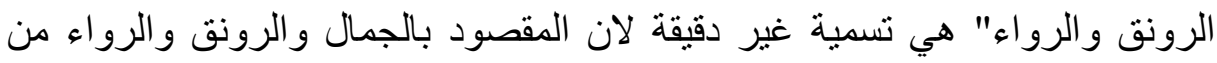

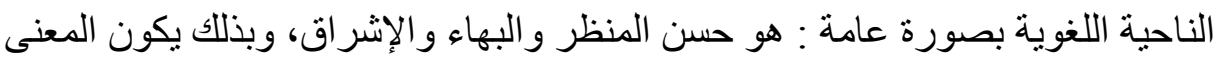

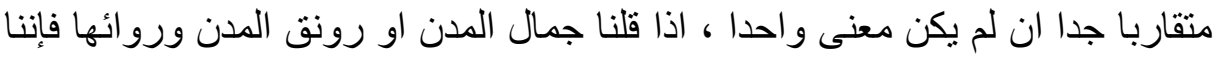

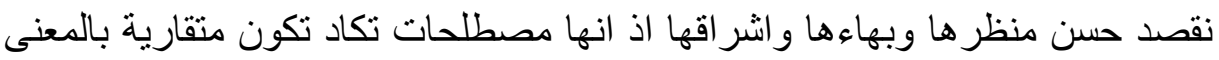
ان لم نقل المعنى نفسه فمصطلح الجمال يدل على رونق المدن وروائها وبهائها و اشراقها وبالتالي نكتفي بذكر مصطلح الجمال فحسب كونها اكثر دقة من الناحية

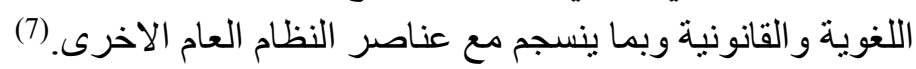
ب_التعريف الاصطلاحي: جاء تعريف الجمال العام عند فقهاء القانون العام بأنه" هو المظهر الفني و الجمالي للشار ع و الذي يستمتع المارة برؤيته". (8) و عرف ايضا بأنه:" حسن المنظر للمكان او هو المظهر الفني الذي يعكس تراثل

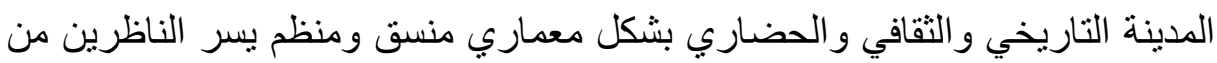

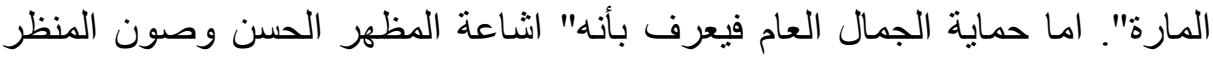

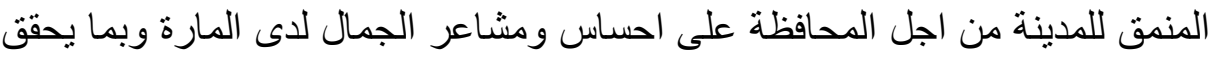

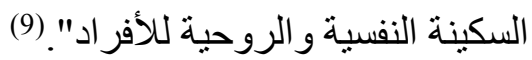
اما المحافظة على عنصر الجمال العام فتعرف" بانها هي الاهتمام بحماية جماليات

الثوارع ورونقها ، حتى لا يصاب عابر السبيل بتقزز في العين لسوء المنظر ". (10) ج_التعريف التشريعي: لقد اولى المشرع اهتماما كبير ا بالجانب الجمالي للمدينة حيث يعد الحفاظ عليه احد

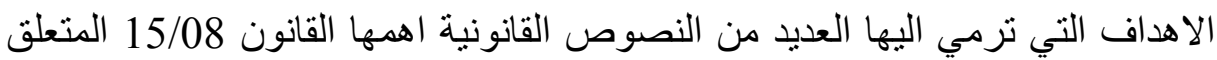

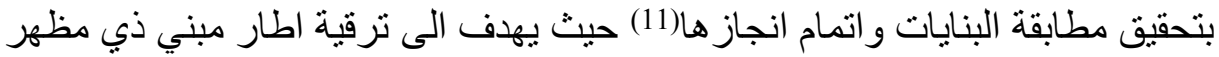

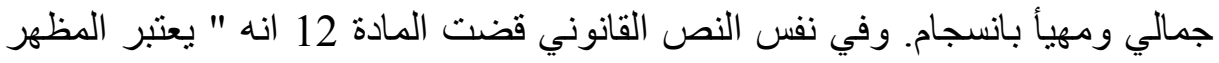

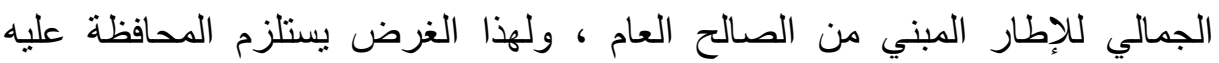
وترقيته".

وعرفت المادة الثانية من نفس القانون المظهر الجمالي بأنه" انسجام الاشكال

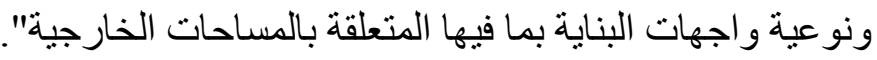


اما بالرجوع الى القانون التوجيهي للمدينة 06_06 (12)باعتباره القانون الاكثر ارتباطا بفكرة النظام العام الجمالي فانه لم يتطرق الى تعريف للجمال المدينة او النظام

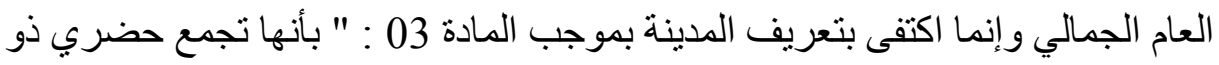
حجم سكاني يتوفر على وظائف ادارية و اقتصادية وثقافية". كما تهدف سياسة المانية المدينة طبقا لمادة 6/6 ، 2 الى: " القضاء على السكنات الهثة وغير الصحية ـ و و حماية

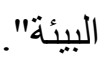

ومن النصوص كذلك القانون 11-04 الذي يحدد القواعد التي تتظم نشاط الترقية العقارية(13)، وبالتحديد المادة 08 منه نجدها تنص على أنه:" يجب ان تسعى التهى كل عملية تجديد عمراني الى جمال الاطار المبني وتحسن راحة المستعملين وكذا مطابقته

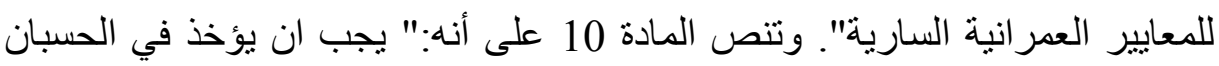

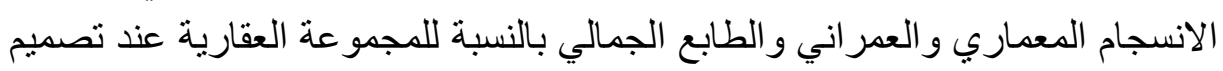

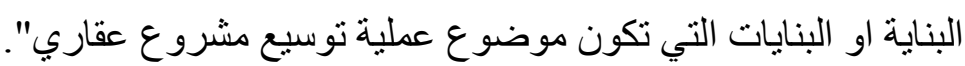
2_ _ _ مقومات جمال المدينة: يمكن حصر اهم هذه المقومات في : المداته أ ــ التخطيط العمراني للمدينة:

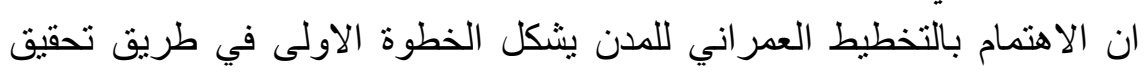

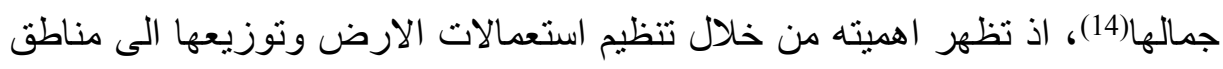

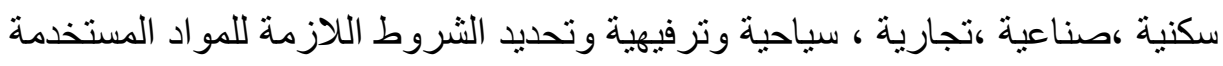

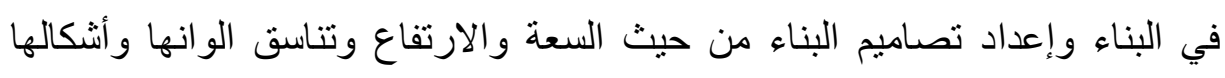

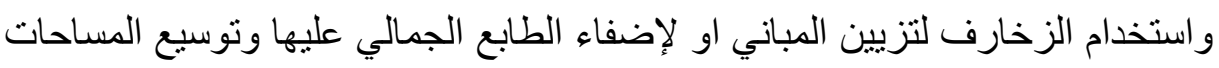

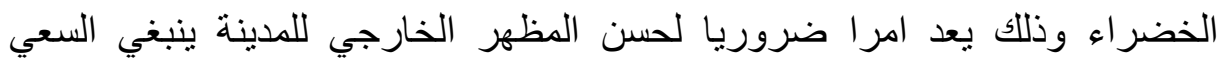
البه. (15)

\section{ب__تجميل المظهر العام للمدينة:}

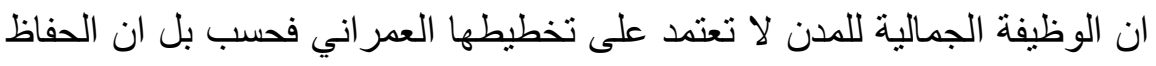

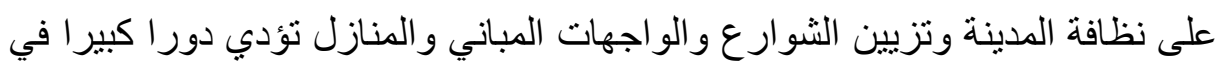
الحفاظ على المدينة ورونقها (16). وفي هذا الصدد فجمال المدينة من الجانب البيئي يتطلب الحفاظ على نظافتها وذلك

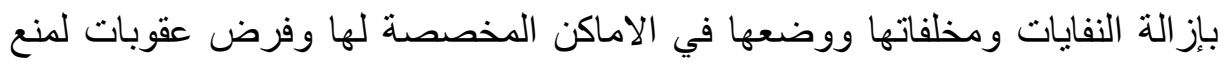

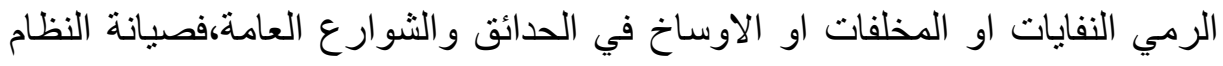

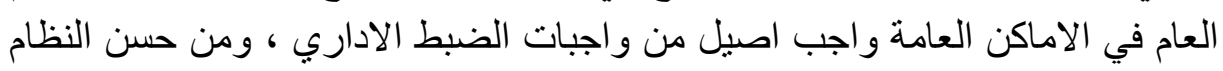

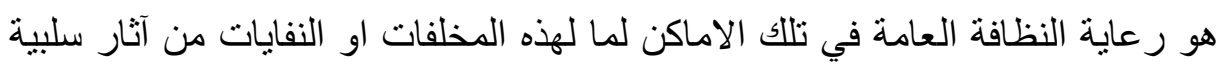
على الصحة العامة لوصفه عنصر المن عناصة الطمر النظام العام. (17)

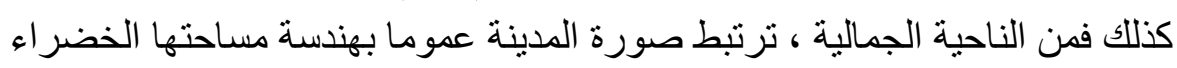
وحدائقها لما تضفيه عليها من لمسات جمالية ، بنباتاتها المختلفة و اشكال تهيئتها

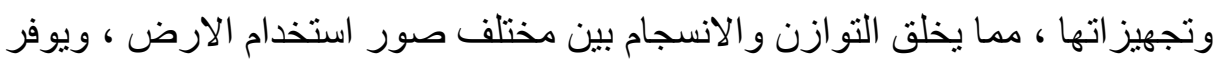

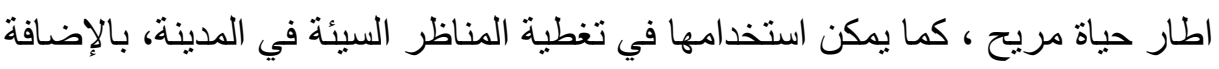


الى اهميتها البيئية حيث تمثل المساحات الخضر اء رئة المدينة فهي تعد أهم معيار يحدد

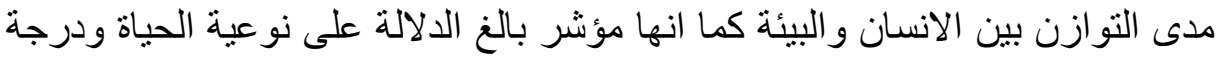

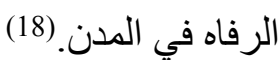

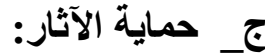

ان جمال المدينة من الجانب العقاري يتطلب الاهتمام بالمباني الاثرية والتراثية

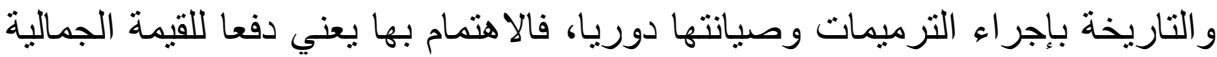

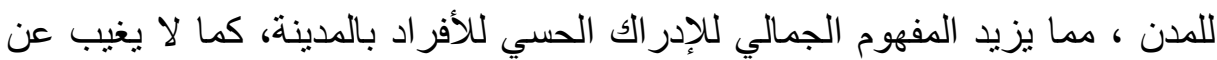
البال الثقافة التي تتشر ها هذه المباني اضافة الى جماليتها(19) .

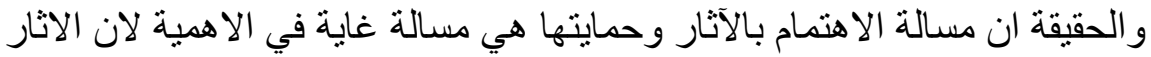

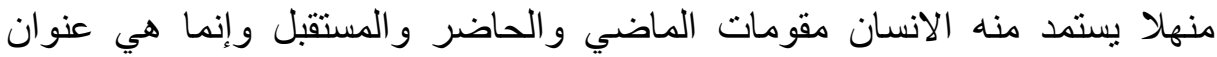

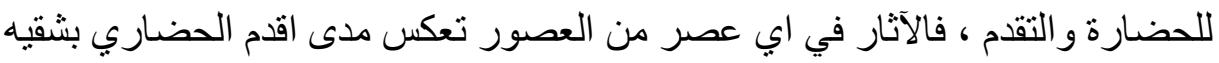
المادي و المعنوي فضلا عن القيمة الجمالية التي تتركها هذه المخلفات المادية(20).

\section{ثاتيا: تعريف التلوث البصري ومظاهره:}

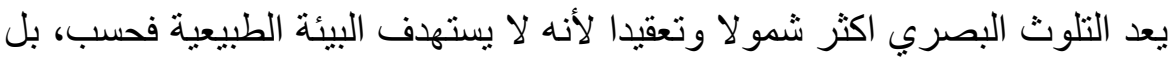

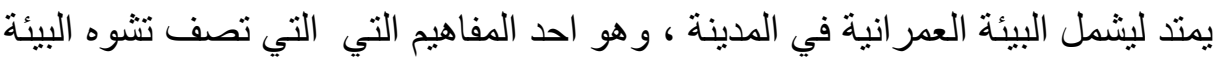
وما تتعرض له من تدهور كباقي انواع الملوثات الاخرى كالتلوث السمعي وتلوث المياه و الهو اء... ، لذلك سنتطرق لتعريفه وتبيان مظاهره. 1 _ تعريف التلوث البصري:

وردت عدة تعريفات للتلوث البصري منها ما يعرفه على انه كل ما يؤذبي البصر

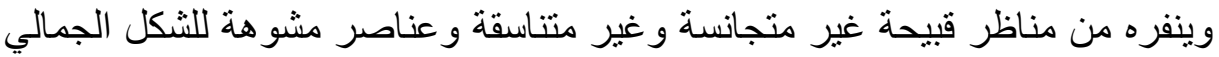

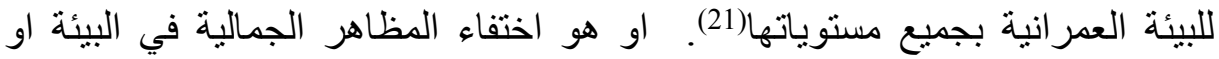
المحيط الذي نحيا فيه(22). وبالنسبة للبيئة العمرانية فهو احداث تغيير غير مستحب في عناصر البيئة ،من شانه ان يمس بقيم الذوق و الفن و الجمال. كما انه تلوث لا يقتصر على المباني بل يمتد

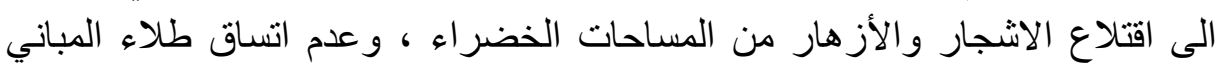

و الكتابة على الجدران و عدم الاهتمام بالموروث الشعبي من ملبس ومباني اثرية. (23) 2 2

يمكن رصد مظاهر التلوث البصري في شوار ع وطرقات المدينة من خلال مايلي:

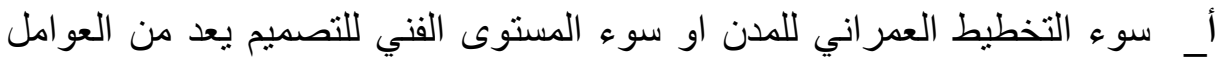

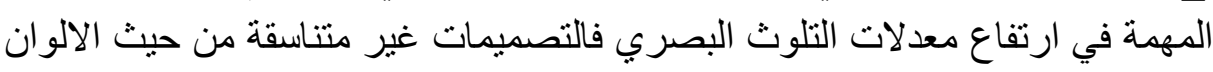

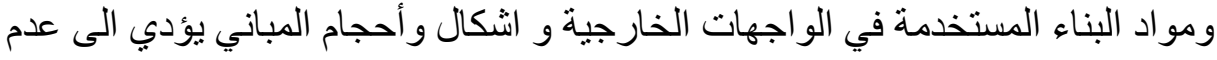
التناسق والتنافر البصري وفقدان التجانس بين المباني والمنشآت المختلفة.

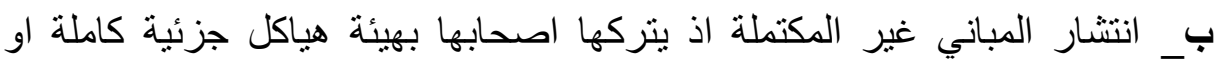
انصاف مباني دون انهاء بناءها مما تخلف منظر ا مشو ها للمناطق المتو اجدة فيها.

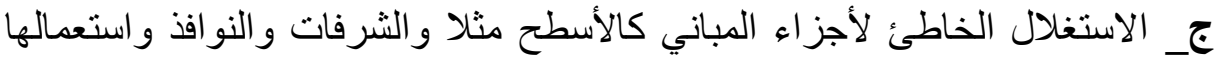

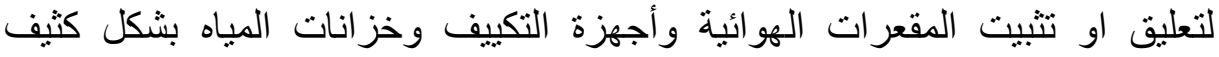


و عثوائي ، مما يشوه المنظر العام للمبنى.

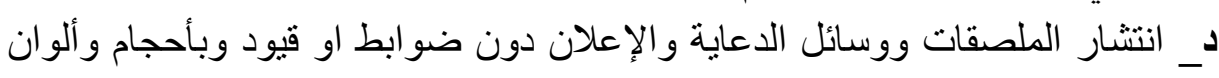
غير متناسقة مما يؤثر على المظهر الحضاري للمدار المدينة.

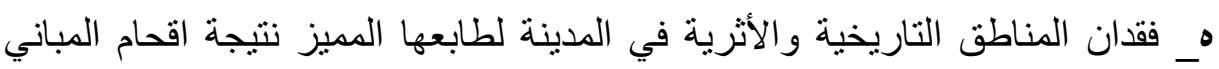

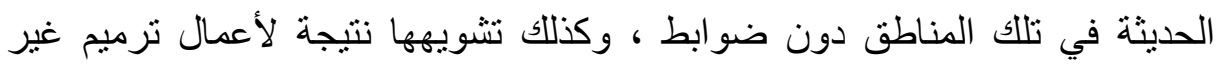

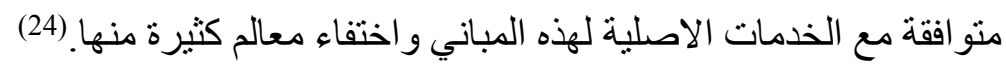

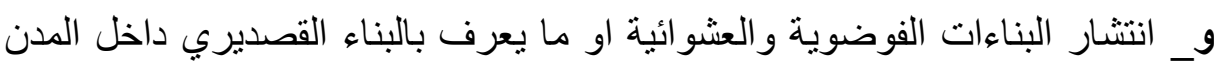

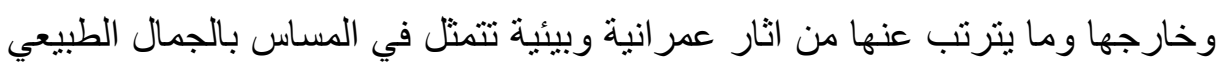

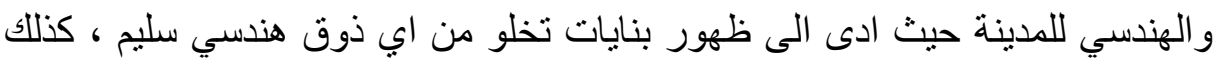

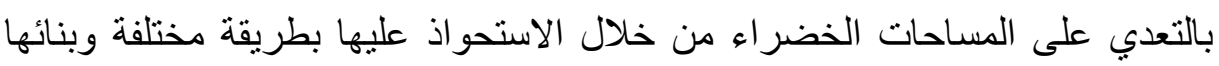

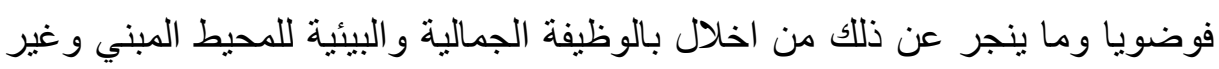
المبني للنسيج العدر اني للمدينة.

المحور الثاني: دور رخصة البناء في الحفاظ على المظهر الجمالي للمدينة:

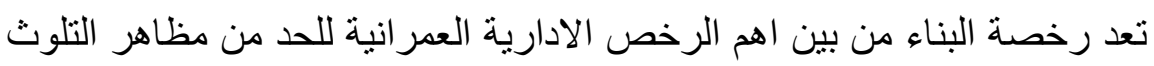
البصري السابق ذكرها، ويتضح ذللك من خلال الشروط الهندسية و القيود البئية البئية

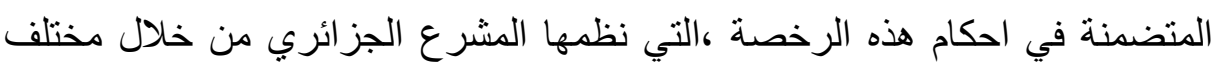

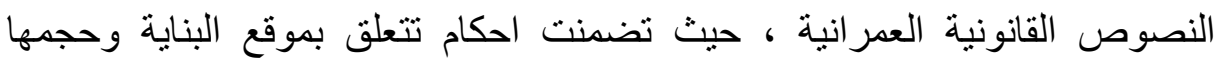

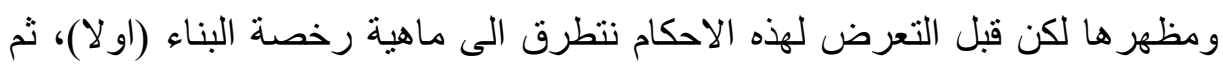

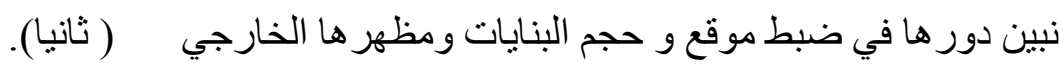
اولا: ماهية رخصة البناء:

بعد تعريف رخصة البناء سنحدد نطاق تطبيقها كمايلي:

1 _ـعريف رخصة البناء ونطاق تطبيقها:

أ_ـ تعريف رخصة البناء:

لم يعرف المشرع الجزائري من خلال القانون 90-29 المتعلق بالتهيئة والتعمير

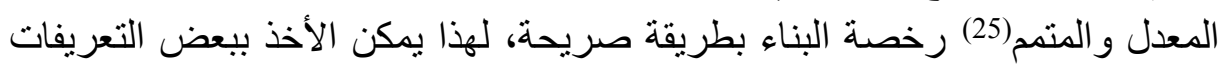

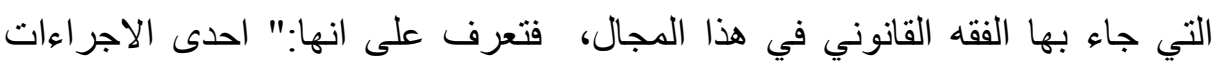

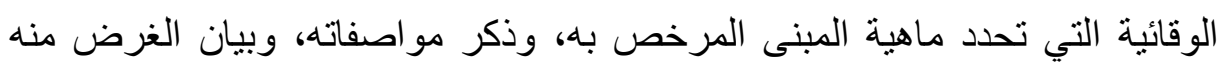

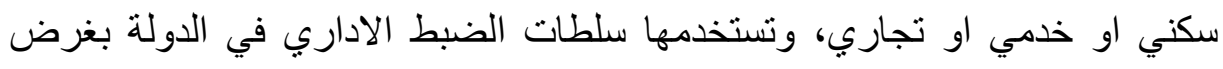
وقاية كل افراد المجتمع من الاضرار التي قد تثنجم عن ممارسة الحريات الفردية ،

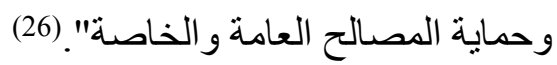
و عرفت أيضا بأنها: " القرار الإداري الصادة الصادة من سلطة مختصة قانونا، تمنح بمقتضاه

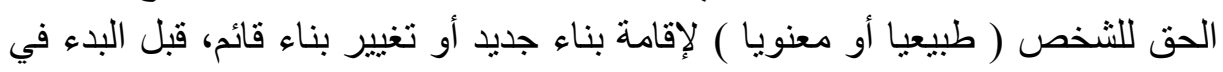

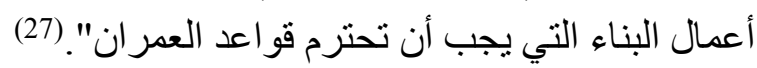

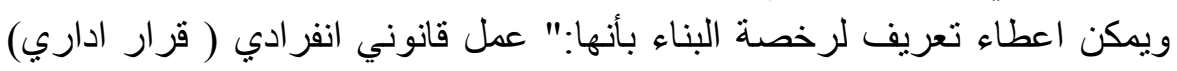

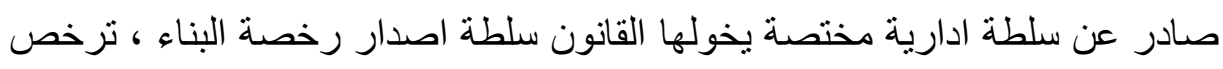

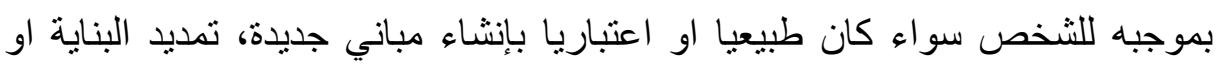


تغيير ها قبل البدء في اعمال البناء مع مر اعاة قانون العمران". (28) ب__نطاق تطبيقها: سنبين نطاقها الشخصي و الموضو الثطي كما يلي:

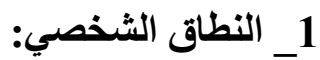
رغم المبدأ المنصوص عليه في المادة 50 من القانون 90-29 هو " ارنباط حق البناء

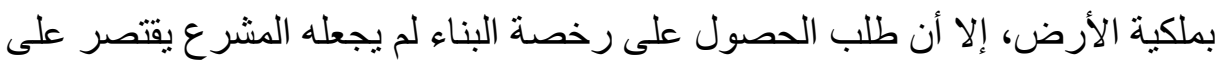
المالك فقط، و إنما منح هذه الصفة لعدة أثخاص جاء ذكر هم حصر ا في المادة 42 من المرسوم التنفيذي

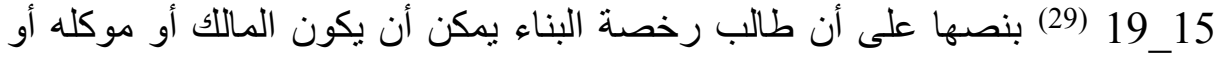

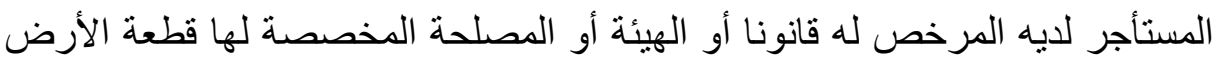
أو البناية، بشرط تقديم ما يثبت هذه الصفة. لهُ لهن و عليه، يتمتع بصفة طالب رخصة البناء كل من:

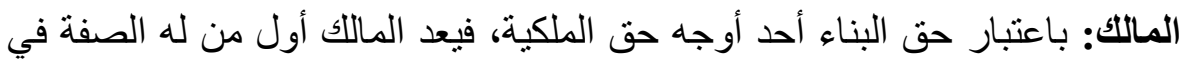

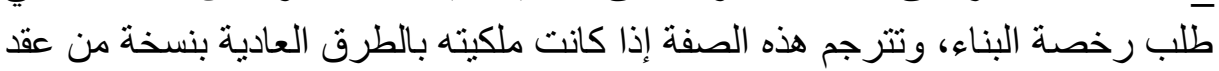

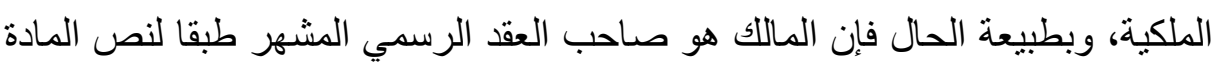

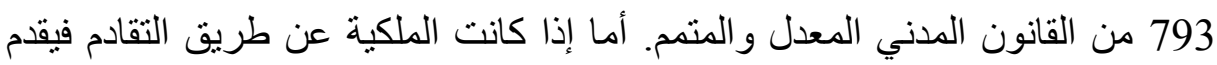
شهادة الحيازة طبقا لما ينص عليه القانون 90-25 المتضمن التوجيه العقاري المعدل

ـ وكيل المالك: يمكن أن يوكل المالك شخصا غيره ليتقدم بطلب رخصة البناء، ويصح

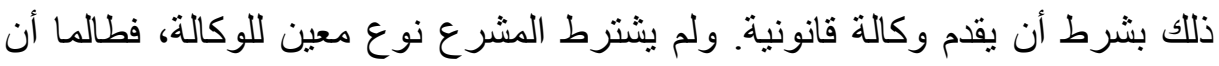
النص عام فيجوز أن تكون وكالة عامة أو خاصة طبقا لنص المادة 573 من القانون المدني المعدل و المتمح.

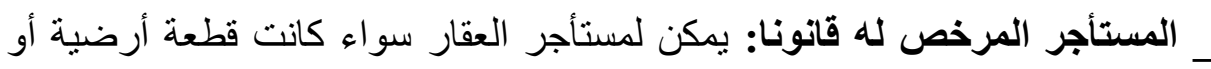

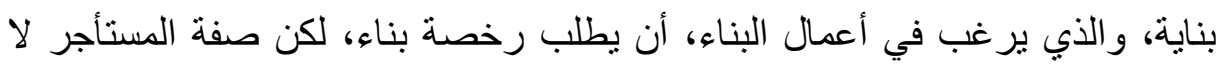
تكفي وحدها لطلب الرخصة بل يجب أن برفق طلبه بترخيص من مالك العين المؤجرة أنساء يرخص لله فيها القيام بأثغال البناء(31). _ الهيئة أو المصلحة المخصصة لها قطعة الأرض أو البناية: فقد أعطت لها المادة 42 الفقرة الأولى من المرسوم التنفيذي 15_19 الصفة في طلب رخصة البهـة البناء المتعلقة

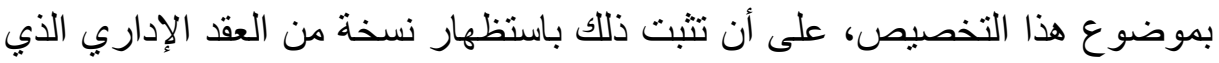
ينص على تخصيص قطعة الأرض أو البناية.

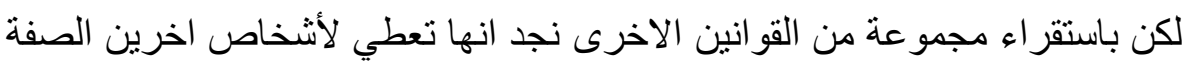

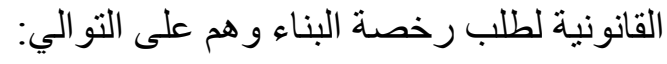

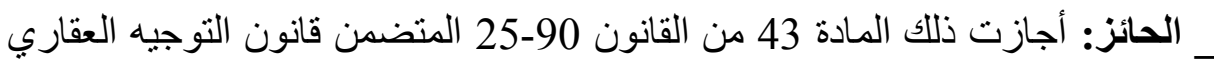

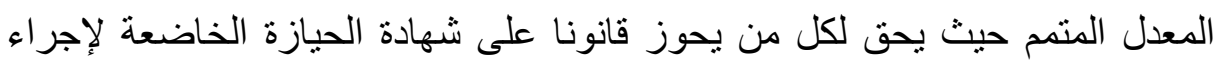

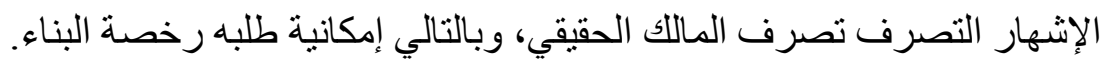

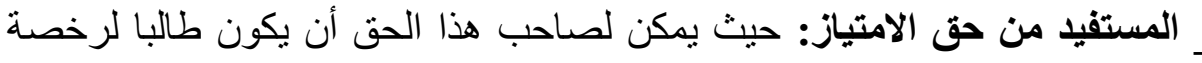

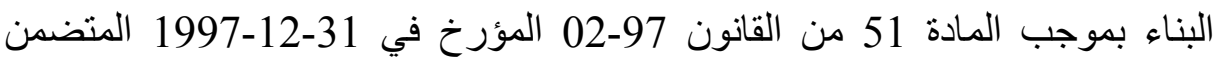


قانون المالية لسنة (32) 1998 المعدلة للمادة 117 من المرسوم التشريعي رقم 93-18

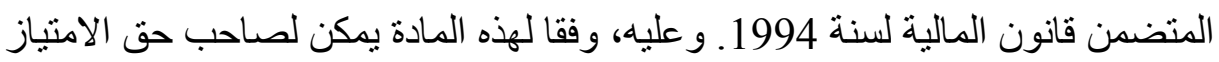

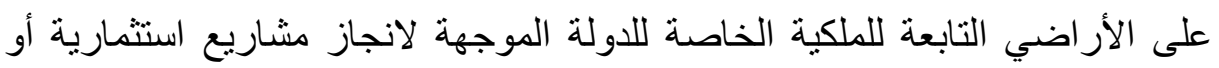

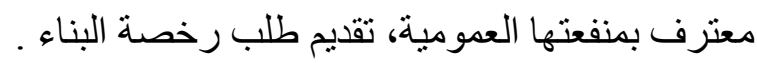

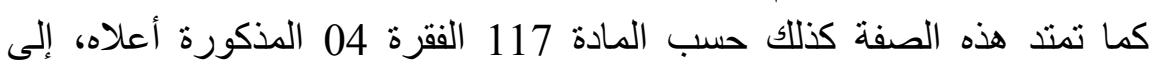

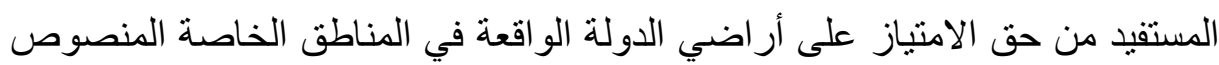

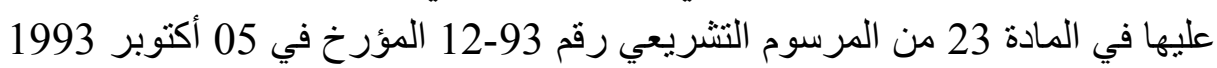

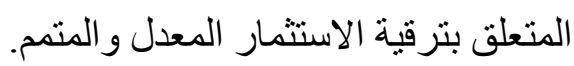
ـ المرقي العقاري: يمكن للمرفي العقاري طلب رخصة الإنة البناء استنادا الى القانون

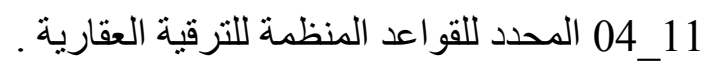
ـــالسلطة المكلفة بالأوقاف: لها الصفة القانونية في طلب رخصة البناء طبقا لأحكام المرسوم التنفيذي 91_81 المتعلق بيناء المسجد وتنظيمه وتسييره وتحديد وظيفته فيكة المعدل و المتمم (33).

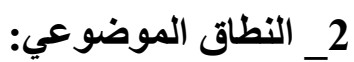

لقد كان مجال فرض رخصة البناء من أولى المسائل التي تطرق لها القانون 90-

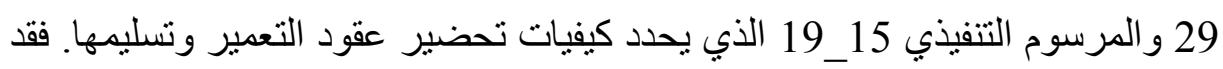
حدد المشرع الجزائري في نص المادة 52 من القانون 15 -19-29 الأعمال التي تستلزم رخصة البناء حيث نصت على انه"" تشترط رخصة البناء من أجل تثبيد البنايات

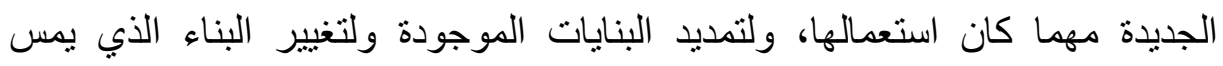

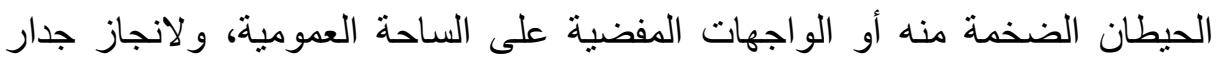

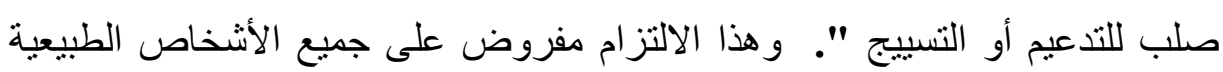
و المعنوية و على مستوى كل الإقليم ومن أجل القيام بالأعمال التالية: كل تثيبيد لبنايات جديدة مهما كان استعمالها. كل تمديد لبنايات موجودة. ـــ كل تغيير للبناء يمس الحيطان الضخمة منه أو الواجهات المفضية على الساحة العمومية. ـ كل انجاز لجدار صلب بقصد التدعيم أو التسييج.

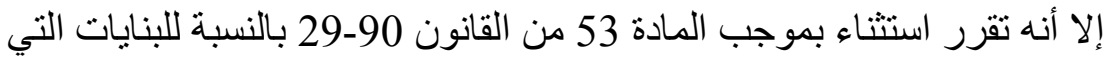
تحتمي بسرية الدفاع الوطني، حيث نصت على أنه " لا تخضع لرخصة البه البناء البنايات

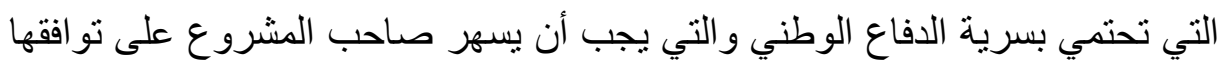

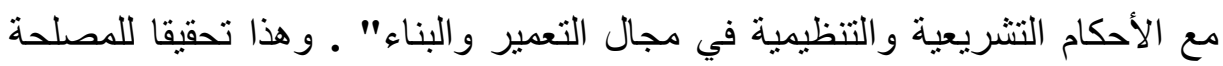

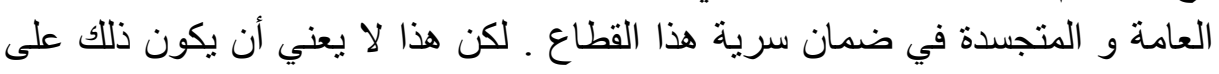

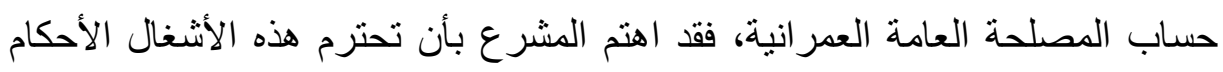

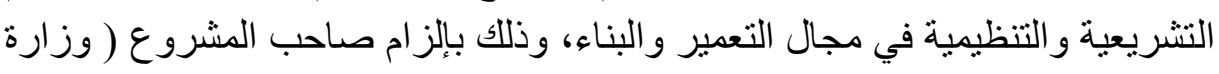

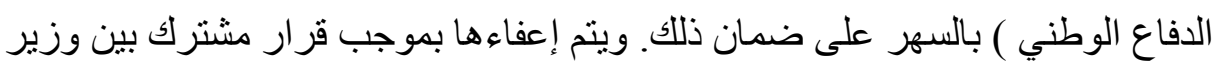

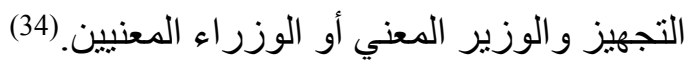


ثانيا:دور رخصة البناء في ضبط موقع وحجم البنايات ومظهرها:

لرخصة البناء دور فعال في مجال ضبط وتنظيم النشاط العمر اني للأفراد حيث

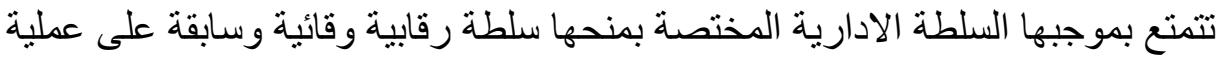
البناء حتى تضمن عدم انتهاك قو اعد التهيئة والتعمير خاصة المتعلقة منها بموقع وحجم التهابة و مظهر البنايات. حيث قضت المادة 46 من المرسوم التنفيذي 19/15 على أنى أن تحضير

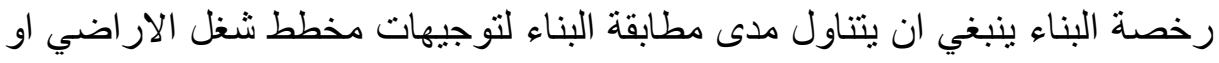

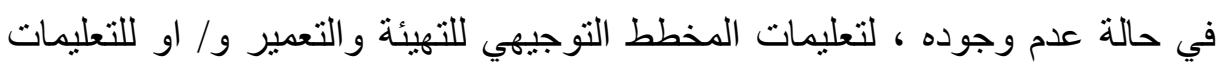
المنصوص عليها تطبيقا للأحكام المتعلقة بالقو اعد العامة للتهيئة و التعمير.

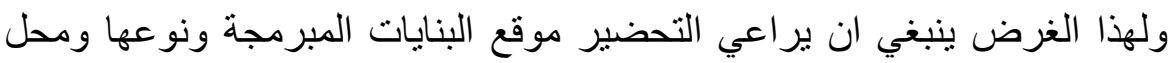

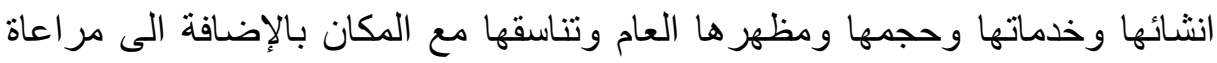

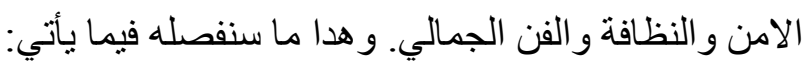
1 _ــور ها في ضبط موقع و حجم البنايات:

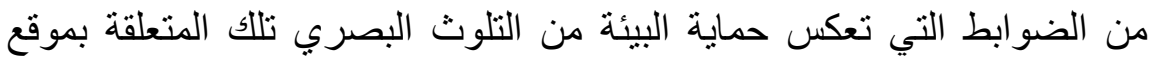

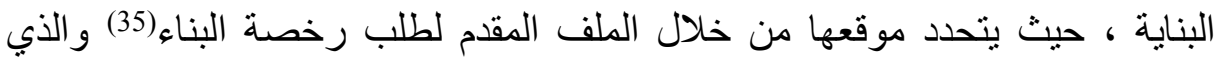

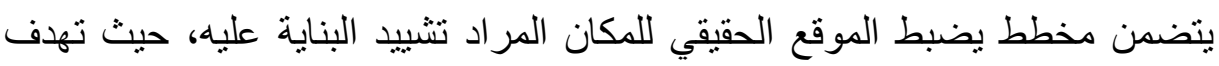

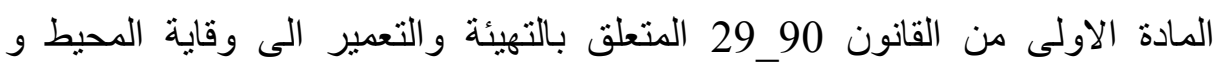

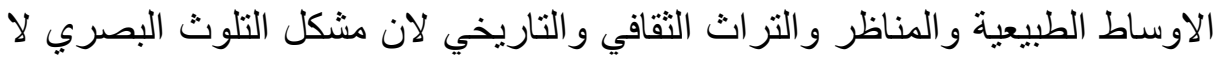
يمس المناطق العمرانية فقط بل يمتد ليمس المناطق الاثرية والسياحية والتاريخية ،

للالك جاءت قواعد قانون التهيئة والتعمير عامة تشمل جميع عناصر البيئة المشيدة(36).

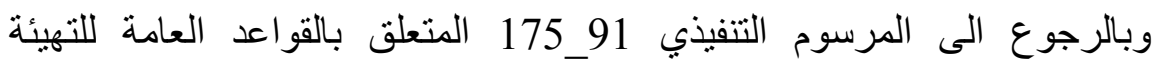
و التعمير (37) قيد منح رخصة البناء بضرورة عدم مساس البناءات بحكم موقعها وحجمها واستعمالها بالأمن العمومي والسكينة العامة والصحة وكذا البيئة والجمال

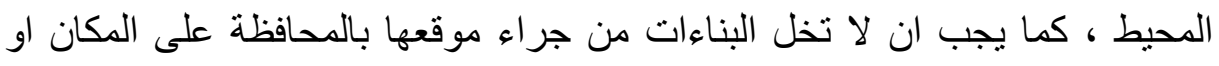

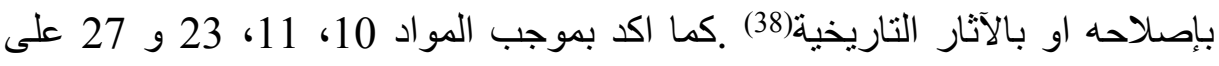
ضرورة التصفيف على طول الطرقات فمثلا لا يمكن البناء على مسافة تقل على بلى 06 امتار عن محور الطريق بالنسبة للطرق التي ليس لها مخطط تصفيف مصادق عليه،

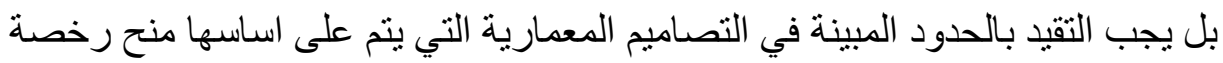
البناء ، لان الزيادة في المسافة المحددة غير مشرو عة كونها تخل بشكل المدينة وجمالها

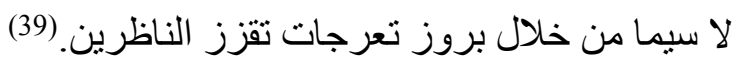

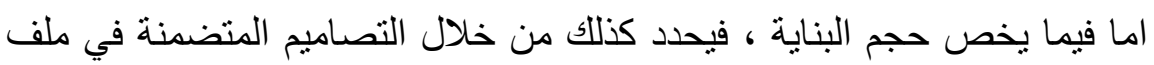

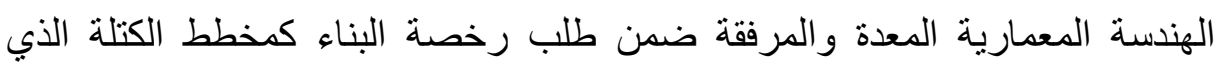

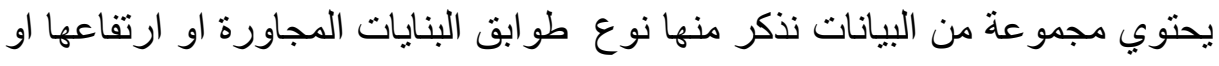

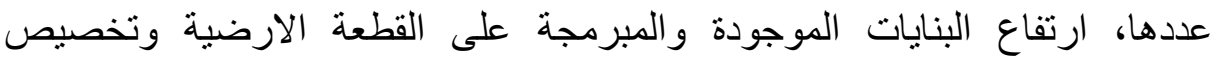

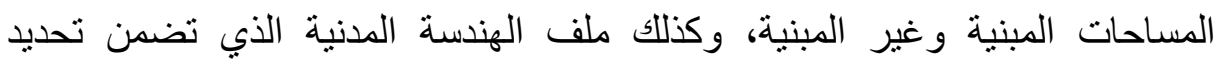
ووصف الهيكل الحامل للبناية ، وكذلك توضيح ابعاد المنشات و العناصر التي تكون

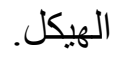
بالرجوع الى المادة 06 من القانون 90_29 يجب ان لا يتجاوز علو البنايات في 
الاجز اء المعررة من البلدية متوسط علو البنايات المجاورة. كما اكد على ضرورة ان

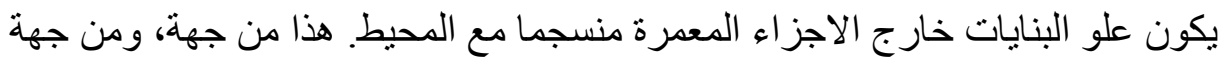

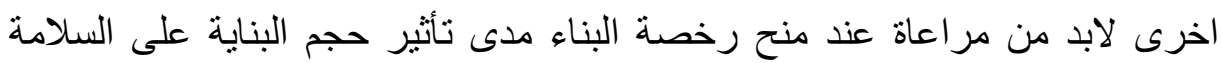

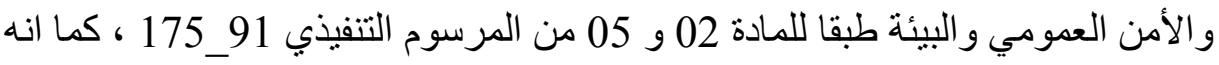

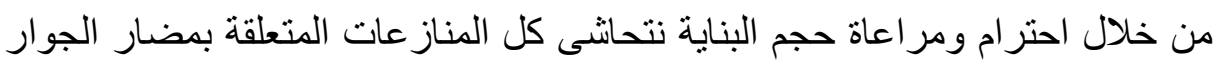
غير المألوفة التي قد تلحق بالجار (40).

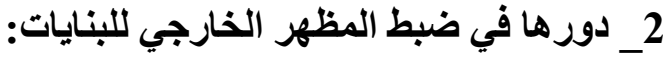

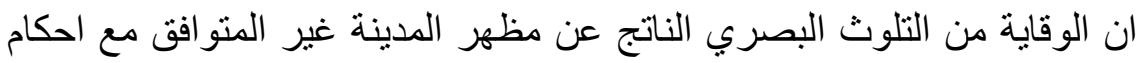

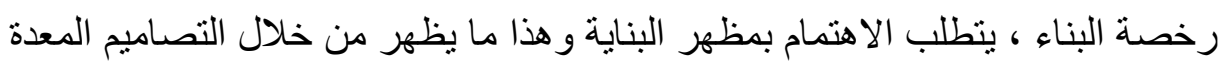

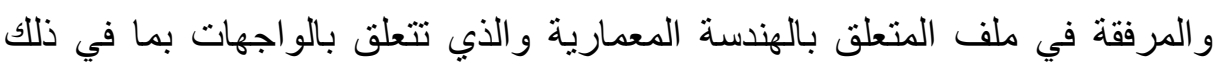

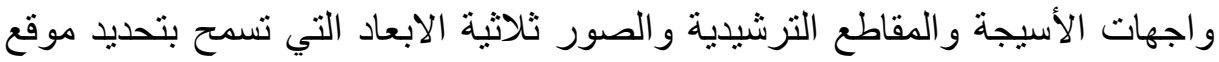
المشروع في محيطه القريب ، كما ينبغي ان يوضح التخصيص مختلف المحلات على التى

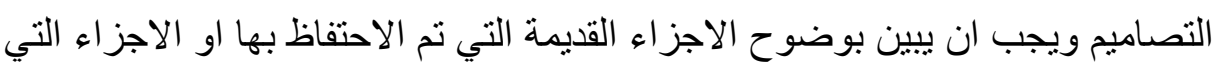

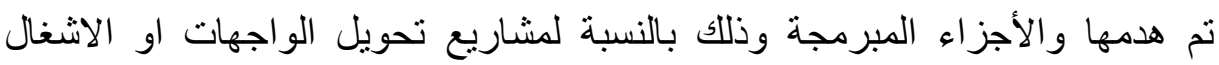

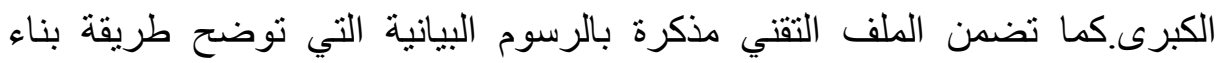

الاسقف ونوع المواد المستعملة.

و أكدت العديد من النصوص القانونية على ضرورة مر اعاة مظهر البناية فمثنا نجد

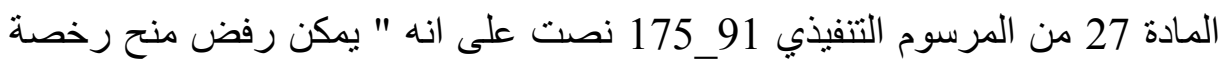

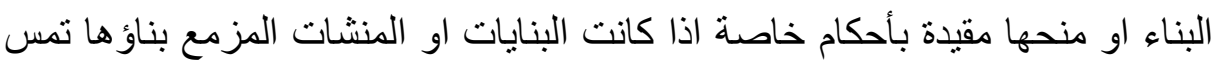

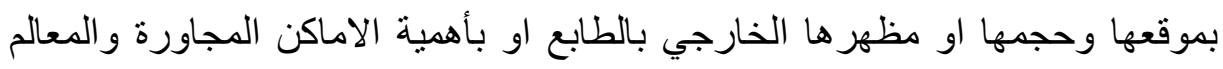

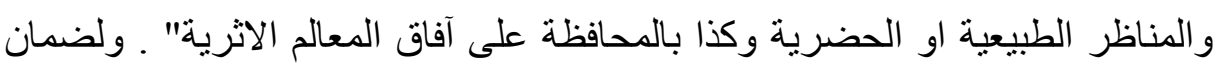

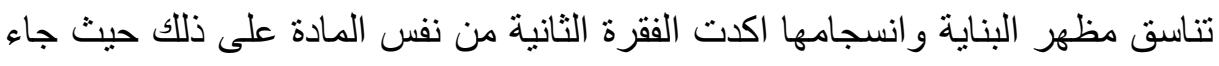

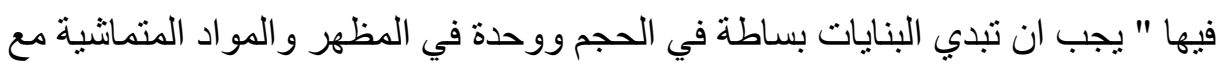

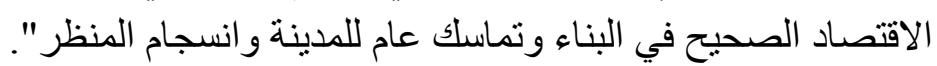
ومن بين اخطر مظاهر التلوث البصري _ ـوالتي تؤثر على الصورة الصاء الجمالية

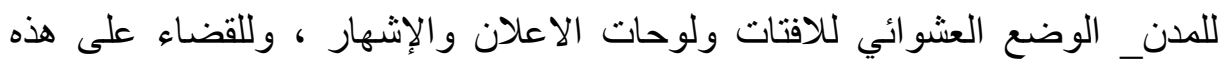

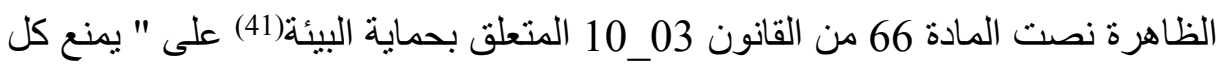

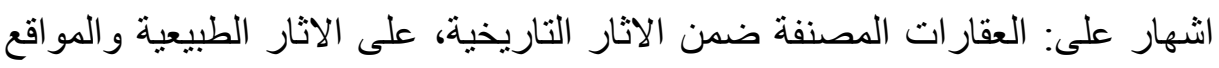

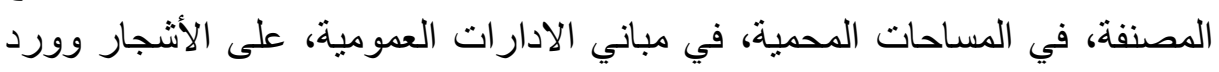

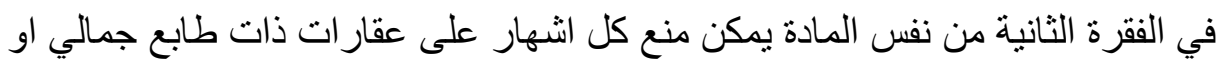

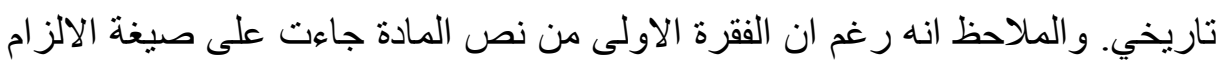

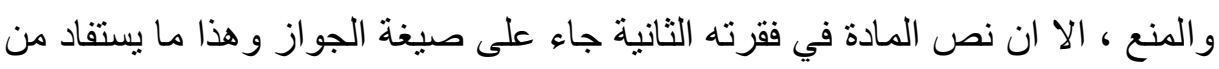

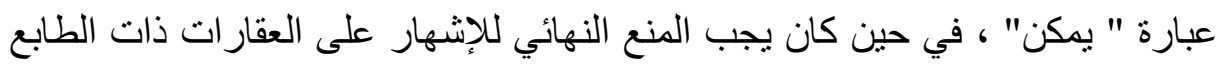

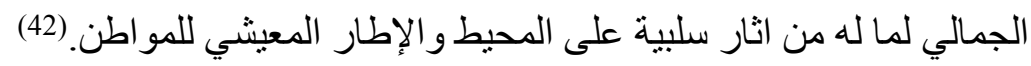


ومن الناحية الجمالية ترتبط صورة المدينة عموما بهندسة مساحتها الخضراء وحدائقها لما تضيفه عليها من لمسات جمالية بنباتاتها المختلفة وأشكال تهيئتها وتجهيزاتها مما يخلق التوازن والانسجام ويوفر اطار حياة وظيفي مريح(43). لذلك ،

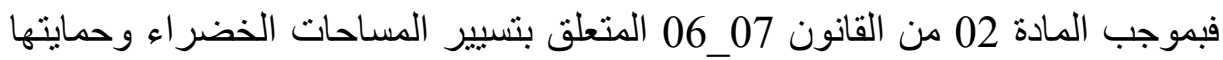

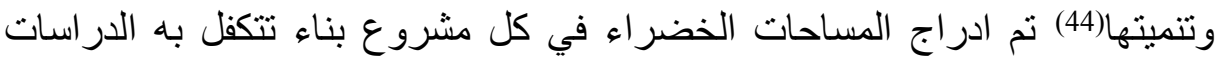

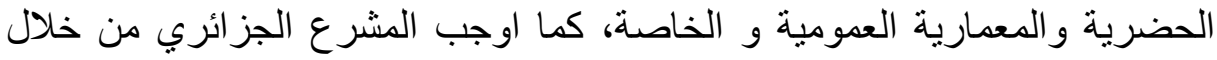
المادة 28 من نفس القانون على ضرورة ان يتضمن العمن او ان يتكفل كل انتاج معماري

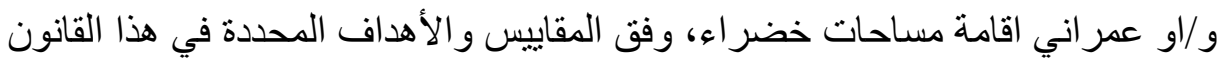

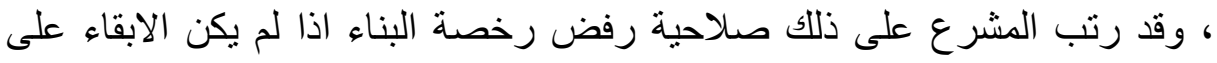

المساحات الخضر اء مضمونا ، او ادى الى تدمير الغطاء النباتي طبقا للمادة 16 منه.

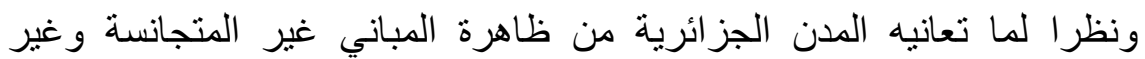

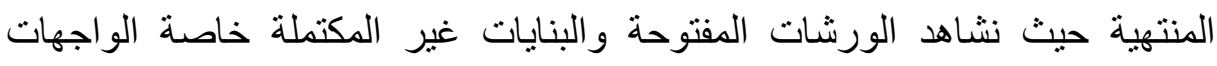

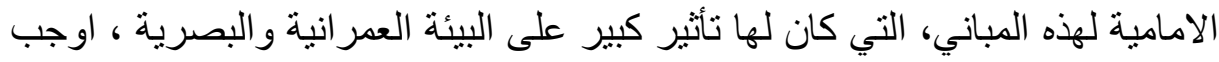
على الدولة التدخل من اجل وضع حد لهذه البنايات وذللك من خلال الصدار التهار القانون

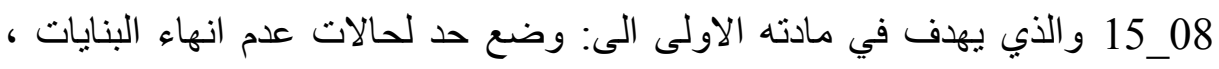

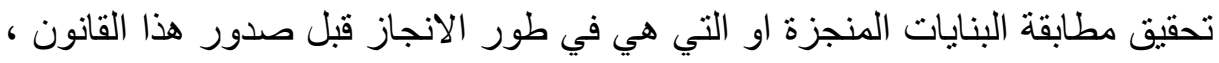
تحديد شروط شغل و/او استغلال البنايات، ترقية اطار مبني ذي مظهرة فئهر جمالي ومهيأ بانسجام، تأسيس تدابير ردعية في مجال عدم احتر ام اجال البناء وقو اعد التعمير.

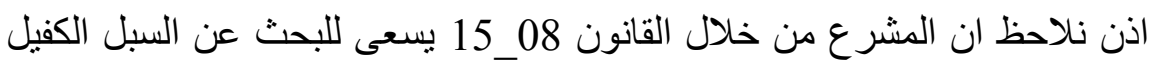

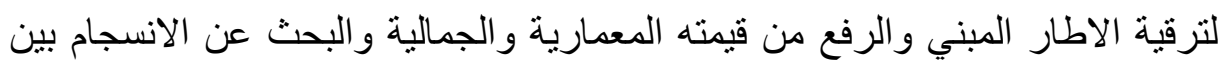
مختلف المباني المشكلة له(45)، حيث عرفت فئ المادة 02 منه المظهر الجمالي بانه"

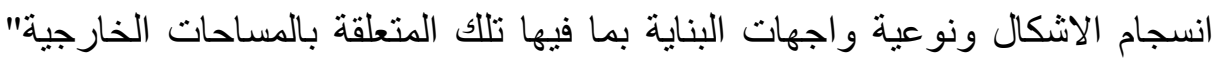
فالمظهر الجمالي للمباني لا يقتصر على شكل المبنى فقط، بل بمتد الى المواد الماد المستعملة

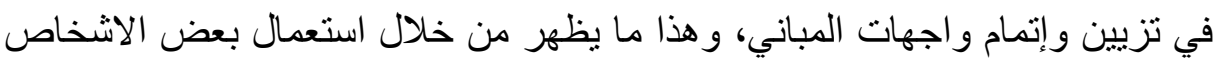

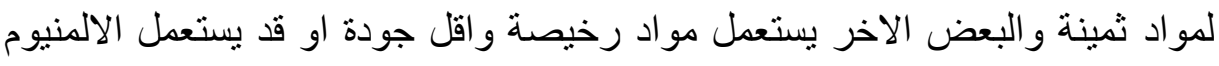

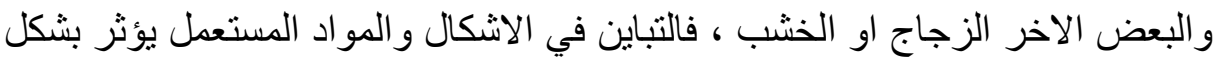
و اضح على انسجام المباني وبالتي يؤثر على الصورة الجمالية للمدينة(46).

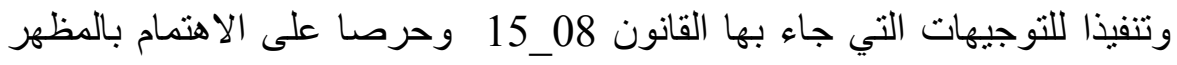

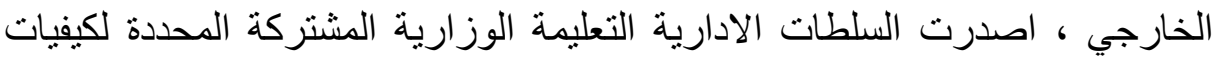

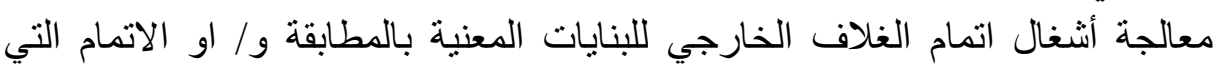

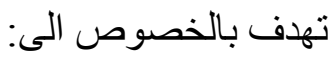
ـ وضع حد لحالة عدم اتمام البنايات الو اقعة على المحاور الرئيسية، مداخل المدن

$$
\text { و التجمعات و المساحات العمومية المعلن عنها كمو اقع ذات الاولوية. }
$$

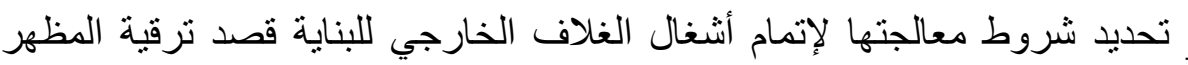

الجمالي للإطار المبني وتهيئته بانسجام. 


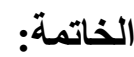

مما تقدم يتبين لنا انه نظرا للدور الوقائي لرخصة البناء في ضبط النشاط

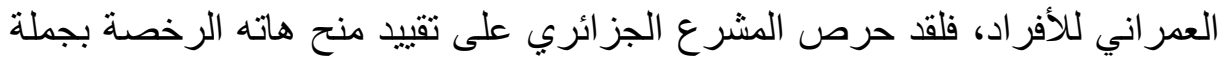

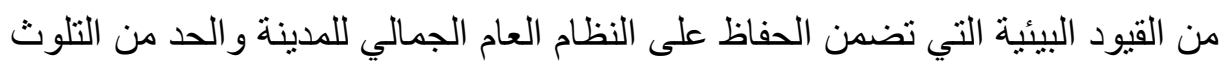

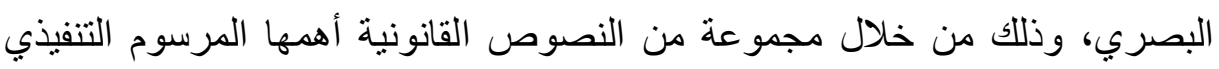

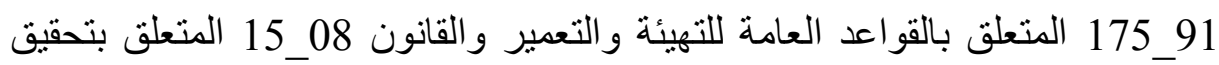

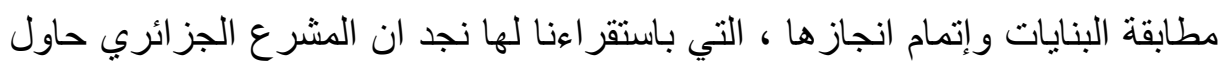

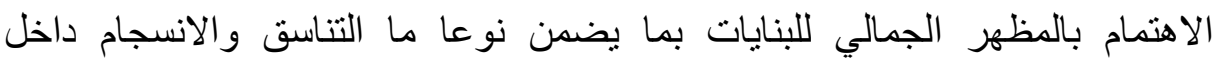
المدينة.و مع ذلك نوصي بمايلي:

_ ضرورة ادر اج هذه القيود مفصلة وبصفة صريحة في في قانون حماية البيئة باعتباره الاطار المرجعي لحماية البيئة. _ اعادة ادر اج در اسة التأثثر في الملف التقني لرخصة البناء نظر الأهميته في التأكد من عدم اضر ار البناء بالبيئة. ــ تفعيل احكام رخصة البناء على ارض الواقد اقع وذللك بتدخل السلطات الادارية

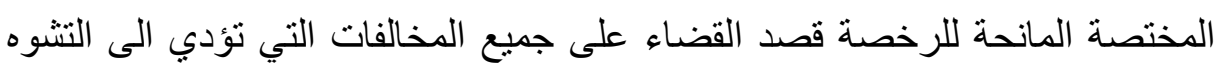
العمر اني للمدينة. ـ التوعية البيئية للفرد بقيمة البيئة وبأهمية حماية الجمال العام للمدينة وضرورة حماية البيئة من مشكلة التلوث البصري وما ينجم عنه من اضرار ومخاطر تصنة تصبيه في صحته

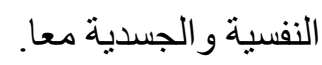

(1) سجي محمد عباس الفاضلي، دور الضبط الاداري البيئي في حماية جمال المدن-

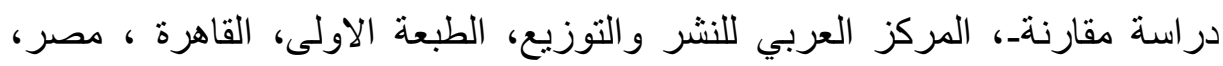

(2) ابن منظور، لسان العرب، طبعة مرجعة ومصححة، المجلد الثامن، الدار الحديث،

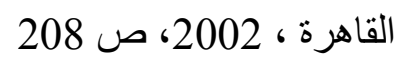




$$
\text { (4) سورة النحل ، الاية 06. }
$$

(5) مريم عثامنية، الرونق الجمالي للمدينة، مجلة العلوم الانسانية ، العدد السادس،

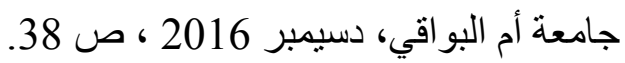

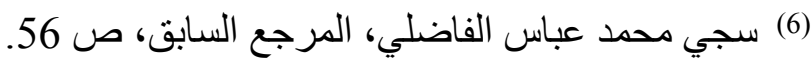

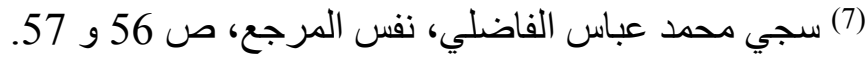

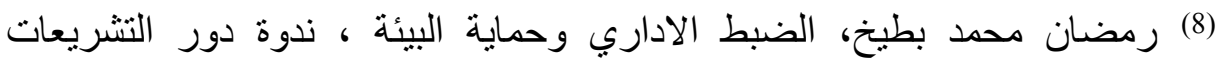

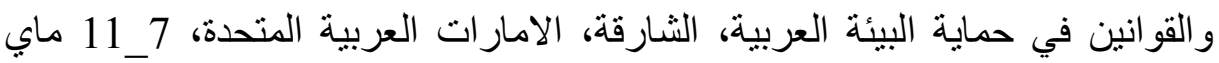

$$
\text { 2005، ص ون } 9
$$

(9) سجي محمد عباس الفاضلي، نفس المرجع، ص صل 65 (10)

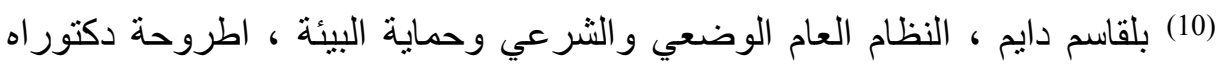
دولة في القانون العام، كلية الحقوق و العلوم السياسية، جامعة تلمسانة المسان،

$$
\text { 29 2004_2003 }
$$

(11) الجريدة الرسمية للجمهورية الجزائرية، العدد 44 ، لسنة 2003 الجية 2008 الجية

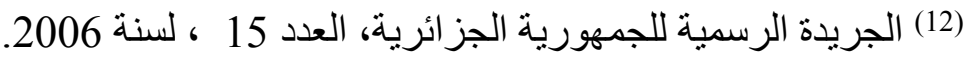

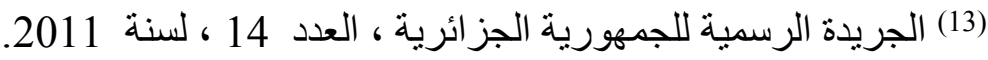
(14) سجي محمد عباس الفاضلي، المرجع السابق،صدية 89. (15) عارف صالح مخلف، الادارة البيئية، الحماية الادارية للبيئة، الطبعة العربية، دار البئية

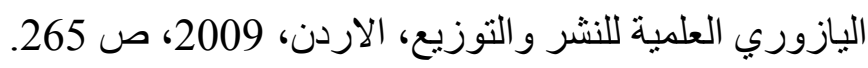

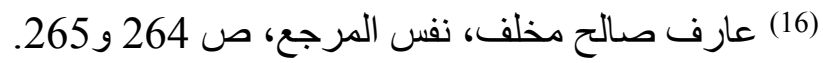
(17) ماجد راغب الحلو، قانون حماية البيئة في ضوء الثراء الثريعة، دار الجامعة الجديدة، القاهرة، مصر،2004، ص 289. (18) محمد الهادي لعروق، البيئة في الجزائر، التأثير على الاوساط الطبيعية

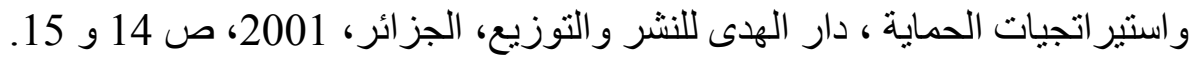

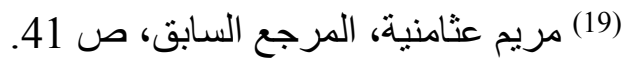

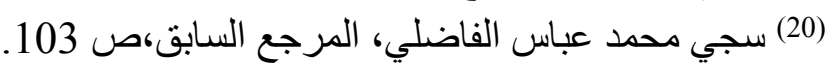
(21) سوسن صبيح حمدان ، اثر التلوث البصري في تشويه جمالية المدن، مقال منشور

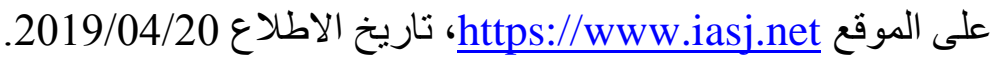

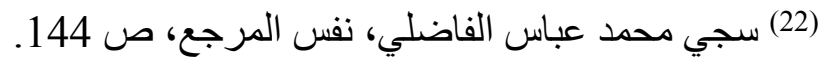
(23) محمد بن عمارة ، مولود دريسي ، التلوث البصري في في المحيط الحضري" مظئ مظهر

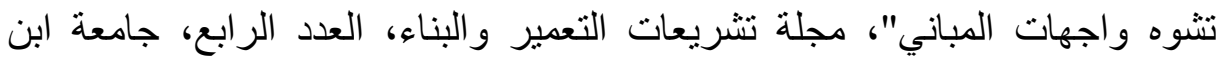

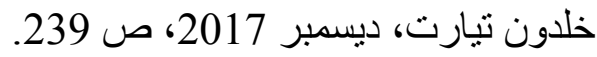
(24) سوسن صبيح حمدان ، المرجع السابق ، صدير صدئ 7 و وما بعدها.

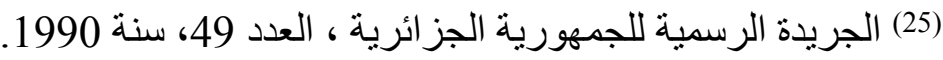

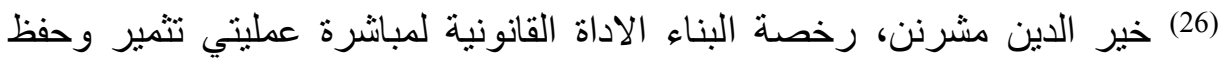

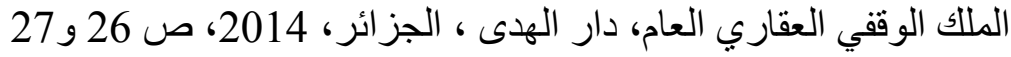

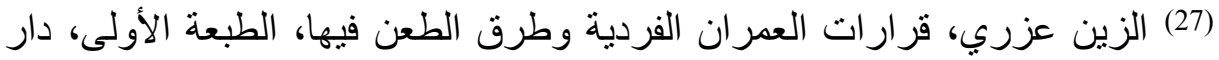




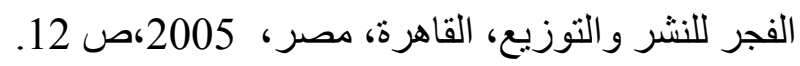
(28) وداد عطوي، الرقابة القضائية على رخصة، التئة البناء في الجزائر ، الطبعة الاولى،

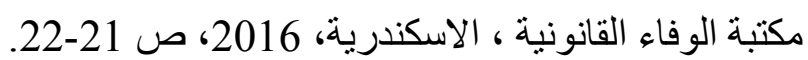
(29) الذي يحدد كيفيات تحضير ، الأنيان عقود التعمير وتسليمها، الجريدة الرسمسة للجمهورية

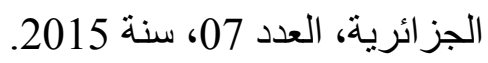
(30) الجريدة الرسمية للجمهورية الجز ائرية، العدد 49، سنة الجنة 1990.

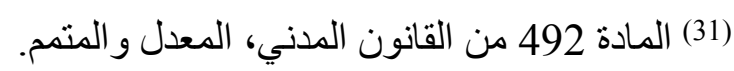

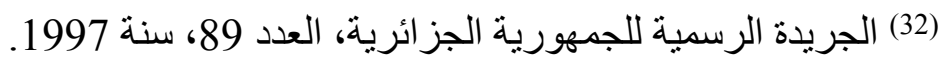

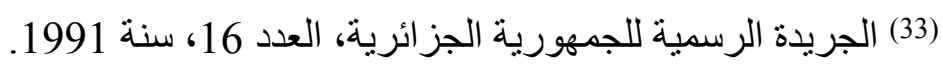

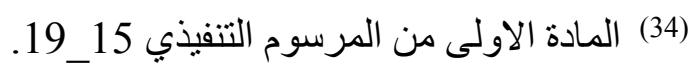

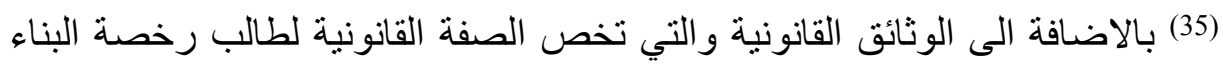

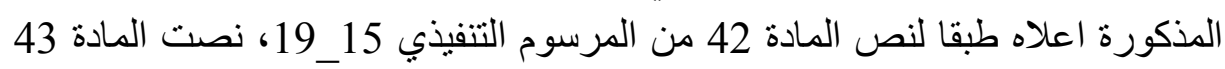

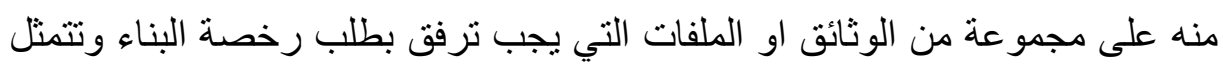

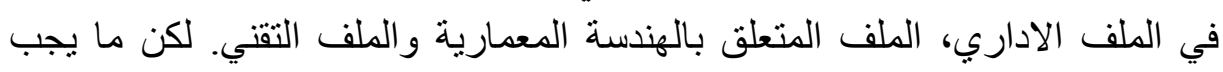

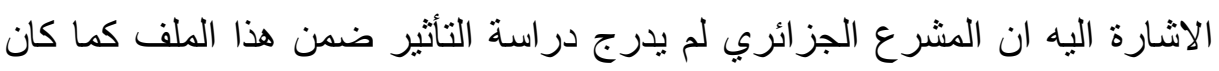

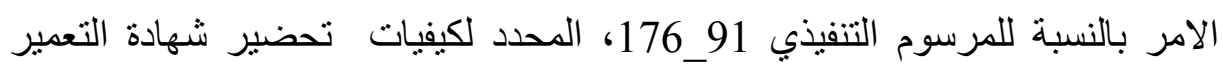

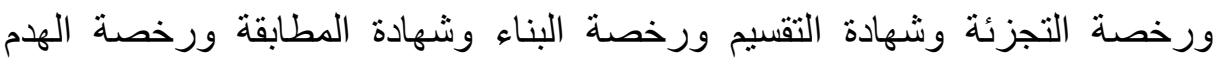

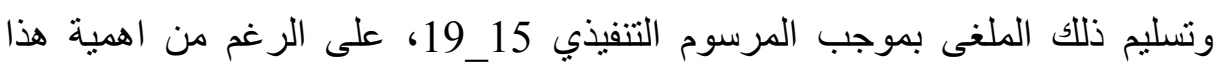

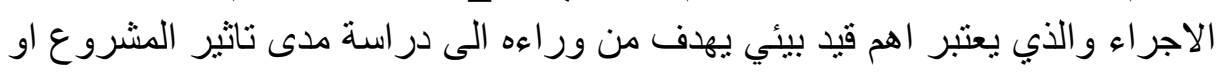

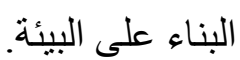

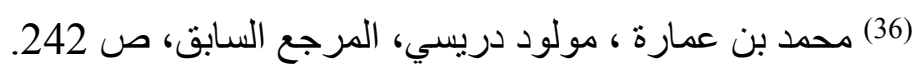

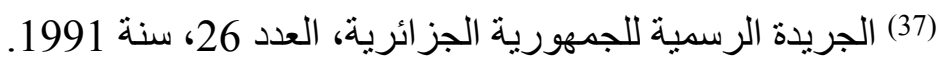

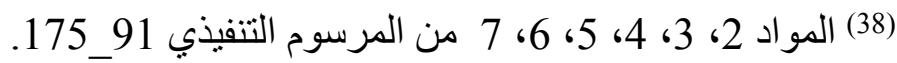

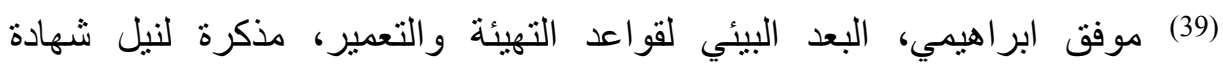

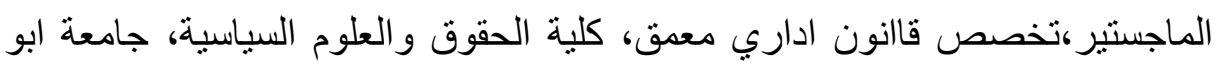

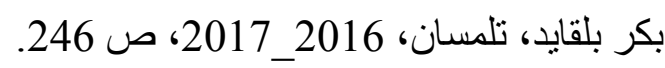

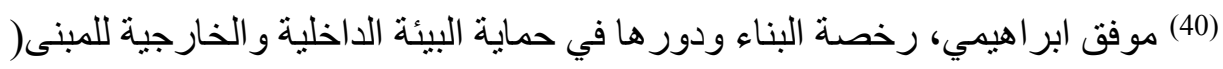

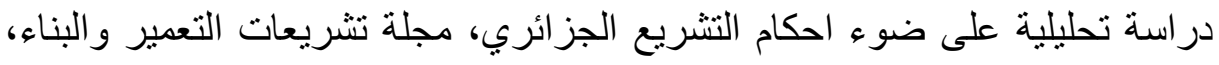

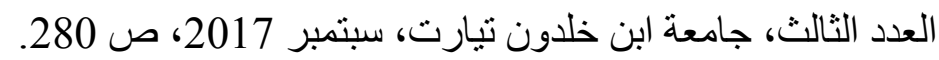

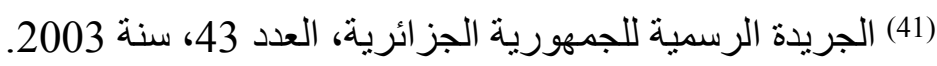

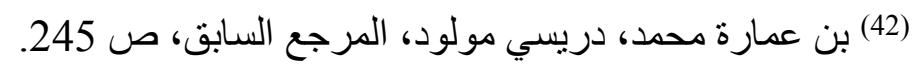

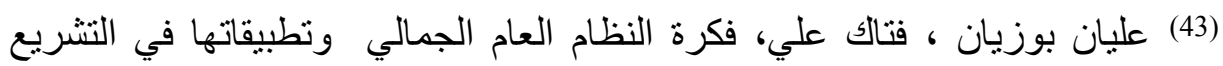

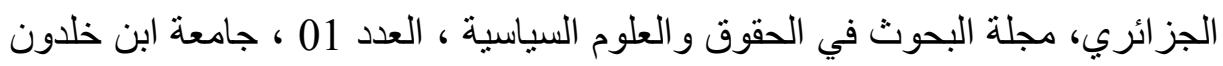

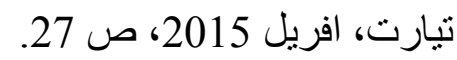

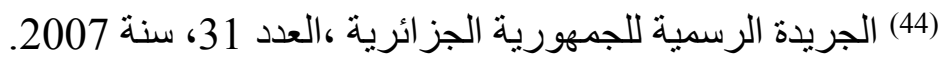
(45) لمزيد من التفاصيل انظر بوشلوش عبد الغني ، القانون 15_08 كالية اللتئية اللتمية 
العمر انية المستدامة للمدينة الجزائرية، رؤية ميدانية بين الامل و التطبيق، مجلة الحقوق

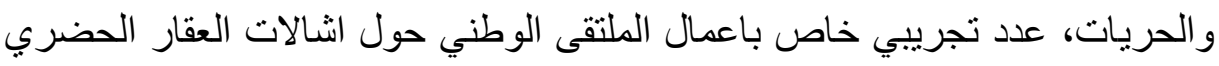

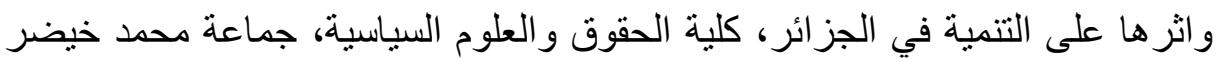

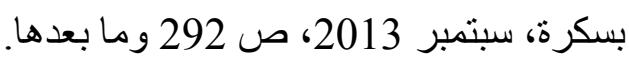

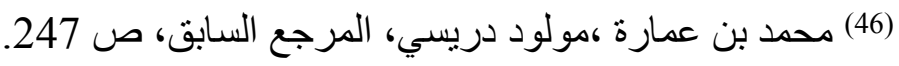

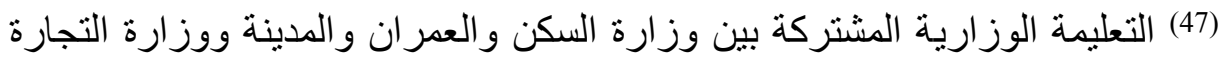

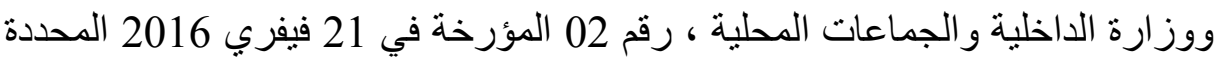

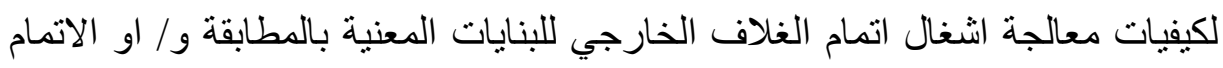

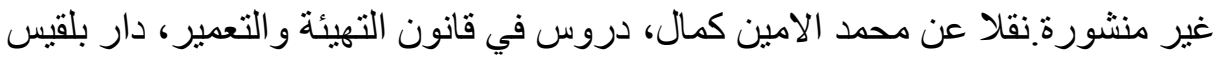

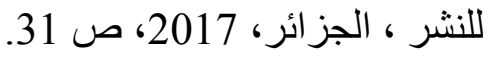

